\title{
Leveraging Networking Groups for Social Shopping with Special Reference to Instagram
}

\author{
T. Gayathri \\ Assistant Professor, Department of Commerce \\ Nehru Memorial College (Autonomous), Thiruchirapalli, Tamil Nadu, India
}

\section{OPEN ACCESS}

Manuscript ID:

COM-2020-08043435

Volume: 8

Issue: 4

Month: October

Year: 2020

E-ISSN: 2582-6190

Received: 05.08.2020

Accepted: 13.09 .2020

Published: 01.10.2020

Citation:

Gayathri, T., and S. Preethi. "Leveraging Networking Groups for Social Shopping with Special Reference to Instagram." ComFin Research, vol. 8, no. 4, 2020, pp. 38-50.

DOI:

https://doi.org/10.34293/

commerce.v8i4.3435

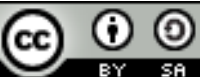

This work is licensed under a Creative Commons Attribution-ShareAlike 4.0 International License

\section{S. Preethi}

Research Scholar, Nehru Memorial College, Thiruchirapalli, Tamil Nadu, India

Abstract

The advent of the Internet and the gradual digitization of select services mark the beginning of a new era in E-commerce and Online access to some facilities that minimize both time and human energy. For example, booking tickets for train travel, air travel, and even bus travel were brought to the fingertips of families which had to otherwise spend a lot of time in long queues before booking counters. Subsequently, other service providers also entered the field with more sophisticated services like booking accommodation, guided tours, and even packaged travel plans. Yatra.com, Make-my-trip, Goibibo, IRCTC, and Red bus are some of the best examples for pioneering efforts that made a considerable impact on services of this kind. In the meantime, the digital platform began to be exploited by new-players who entered the fray with products in almost all walks of life, such as clothing and fashion, beauty care, electronic goods, consumer durables, and even essentials of life such as groceries, fruits, and vegetables. The entry of big- players such as Flipkart and Amazon took online shopping to the next level.

Keywords: Digitization, Social Media, Consumer, E-commerce, Networks and Advertisement

\section{Introduction}

Over the last decade, digitization facilitated Cab services, food delivery, and even specialized services like medical consulting, attenders for geriatric patients, and even service of electricians, plumbers, and domestic help. On a higher level, beautification services at home also started picking up in Tier - 1 cities in a big way.

The consumers in recent times are spoiled for choice because of innumerable options available for any product that is sought after. Originally, they used to rely on recommendations from friends, family circles, or even advertisements. However, the emergence of social networking sites and applications has led to a new concept called "Social Shopping," which consumers began to rely upon for reviews and suggestions. The presence of many people in social media sites like Facebook and Instagram and closed groups in WhatsApp have made this aspect very popular in the last five years. Any product that a consumer needs can be looked up for both alternatives and recommendations from these networks. More significantly, the presence of Google enables the producers to follow and analyze the purchase behavior of a consumer and make recommendations for new products that come into the market to cater to their needs. In these contexts, an attempt at understanding the perception of consumers about social shopping would be relevant because this concept has gained momentum in recent times and may well be the next game-changer as a marketing strategy. 
Study Objectives

This study is carried out with the following objectives,

1. To document the evolution of E-commerce and the use of social media for the same.

2. To critically examine the acceptance of social shopping among consumers.

3. To capture preferences and purchase behavior of women with special reference to beauty products through Instagram.

\section{Literature Review}

Pete Boyle, 2020 suggested two things that are needed to develop a successful online business. The first is the product that helps in solving the problems of the people, and the other one is that which is easy to buy and which activates and engaged the customers. His findings included 147 billion active users of Facebook, $60 \%$ users of Instagram, 30\% of online shoppers, and he found that social media messenger is involved in creating the ROI champion of e-mail's outperformance. Shanelle Mullin, 2019 shared three social media sites such as Facebook, Instagram, and Pinterest as they are occupying the social commerce space. He insisted that about $70 \%$ of followers use Instagram for the discovery of the products. He also pointed out the words of Heidi Cohen, who highlighted the importance of technology, social media platforms, and online shopping as aided to social commerce. According to Heidi Cohen, 74\% of consumers depend on social networks to make their decision on the purchase of the products and also concluded that social commerce is one of the growing trends in this era. Andy Wooley, 2019 explained retail marketing in which businesses and brands are trying their best to convert social media platforms into sales networks. He highlighted some of the reasons to involve social media for the retail business, and that includes higher customer retention and loyalty, an increase of engagements, convenient offers, a high ranking of search to attain the audience with balanced growth. Conor Bond, 2019 suggested that consumers are fond of going to malls after the release of 'Beverly Hills' in 2005. He termed social shopping as a discovery and inspiration on the social network platforms, which helps the user to reflect their feeling upon it. He found that about $60 \%$ of users on Instagram admit that they find new products to buy on the apps. He also insisted on the secret weapon, which involves the implementation of social shopping strategies into the accounts as many of the users are involved actively in discovering new inspirations to make their next purchase. Nikki Gilliland, 2018 recorded that according to the salesforce, the millennials of $54 \%$ utilize the social channels to research the products before perceiving it.

The survey by SUMO yields $82 \%$ of shoppers utilizing the social buy buttons and the other forms of social commerce. Based on BI Intelligence, retailers of the top 500 gained $\$ 6.5$ billion in 2017 and $24 \%$ in 2016 for social shopping. Marketing week reported that about $33 \%$ of people in the age group of $18-24$ are fonder in purchasing products from Facebook directly. He concluded that Instagram offers a consistent shopping experience in which users buy products without being directed anywhere. Aimee Millwood, 2015 implied his findings that social increased to $200 \%$ from 2014 to 2015 in terms of the shares of E-commerce. He also stated that social commerce is in the top list of predictions in the Google search. He made a statement that the brands cannot enter social commerce without the implementation of strategies to increase their brand awareness and helping the customers in purchasing the products. He highlighted the Pixlee's E-commerce stats that 74\% of consumers rely on social media before making a purchase, and $43 \%$ of consumers buy the product only after learning about it on social media. Rainer Olbrich et al., 2011 stated that Social Shopping Communities (SSCs) are the bridge that connects the social networking and online shopping, and he explained that SSCs shopping features are based on the user as they are involved in gaining high rate of growth in the popularity of the consumers. They are helpful in forecasting the purchasing behavior of the consumers.

These studies have highlighted the relevance and impact of social shopping and E-commerce aided by social media. Based on these observations, this study attempts to bring out the critical role of INSTAGRAM as an enabler of social shopping with a special focus on beautification and personal care products. 


\section{Analysis and Discussion}

The economic implications of E-commerce and Social shopping have transcended all expectations and as assumed unimaginably high proportions. The reaching out to a customer has never been so easy today, Thanks to Social media and networks. Facebook and Instagram have become instantly popular because of the wide reach and seamless access to information for the business and the consumer. This is particularly so when it comes to products more than services, though services are fast catching up in recent times. Products ranging from residential real-estate of high value and other products that cater to the needs of the consumers like fashion, footwear, handbags, electronic items, including mobile phones and personal care and beauty products are available at the click of the button. The staggering volume of business that is enabled by social shopping is a phenomenon that needs to be taken note of by manufacturers and service providers. Facebook, with a user base of close to 2.5 billion, is closely followed by Instagram with 1 billion as in April 2020. The chart shown below brings out the details of various social media sites in terms of usage.

\section{Figure 1: Popular Social Networks}

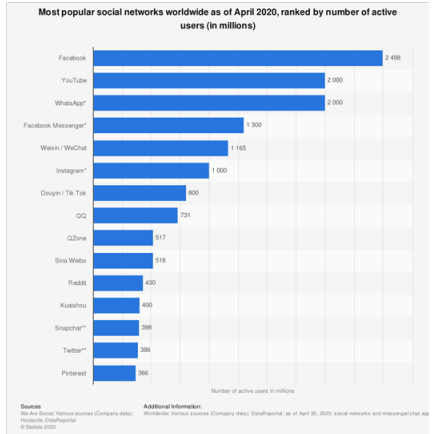

It is evident from the above that Facebook is on top with a user base of over 2.5billion, followed by YouTube, WhatsApp, Facebook Messenger, WeChat, and Instagram. The gap between Facebook and Instagram has been narrowing over the year, and it will not be long before Instagram catches up with Facebook and even surpass it. What started as a medium of posting photographs has now developed into a potential social shopping marketplace with brands reaching out to consumers. The chart shown below captures the rapid strides made by Instagram over the last 5.5 years till June 2018 .
Figure 2: Instagram Users - January 2013 to June 2018

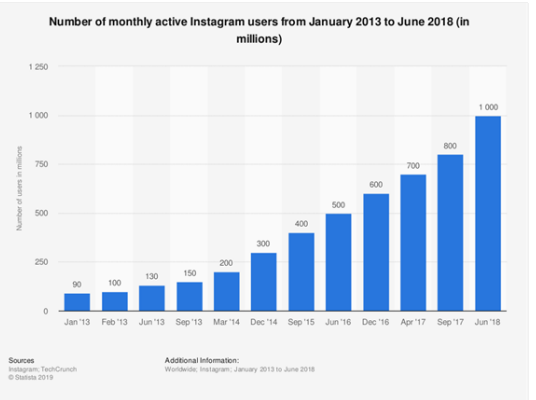

It can be observed that the number of users doubled in a matter of 1 year between 2013 and 2014. After that, Instagram was steadily adding a minimum of 100 million users every year and on at least two occasions, once in 2015 and 2016 when it added 200 million to go up from 400 to 600 million, and again in 2017 and 2018 when it jumped to 1000 million in January 2018 from 800 million in September 2017. The climb has been very steady and very rapid as well. At this rate, it may well overtake Facebook by 2022 if the current trend is any indication. A countrywise break up of users is depicted by the chart shown below.

Figure 3: Leading Countries on Instagram

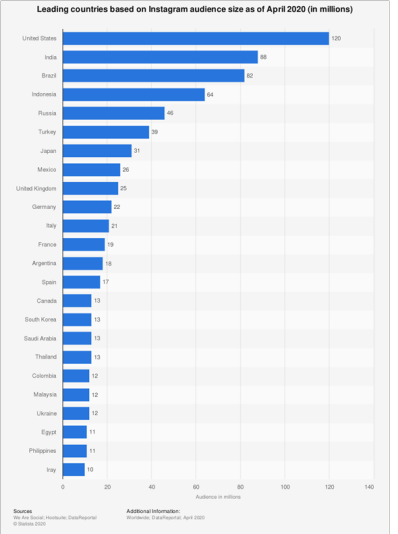

Although the compelling preference for shopping in stores, malls, hyper-mart, or even commercial streets is still alive, the shift towards online shopping or social E-commerce has been on the rise continuously. In a country like India, with a population of over 1.3 billion, the potential market for products and services has been growing tremendously over the year. This can be attributed to the favorable demographic dividend, with more 
than $60 \%$ of the population cohort in the age group of $18-50$. Since the tech-savvy younger population is more inclined towards exploring social shopping as an option, E-commerce portals have begun to leverage this advantage by positioning themselves in all the popular social media networks. The chart is shown below clearly underline this aspect of usage of Instagram in India.

\section{Figure 4: Instagram Users based on Age and Gender}

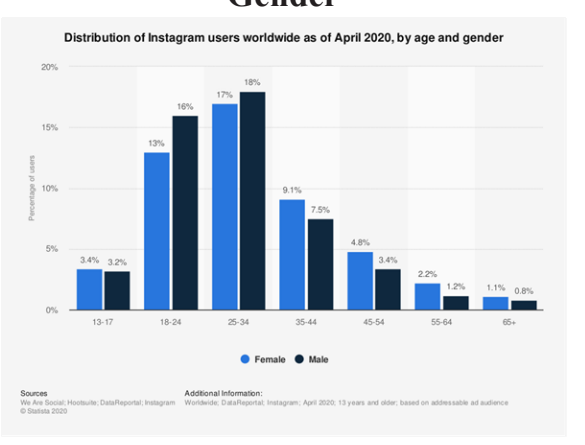

The chart reveals the domination of youngsters in using Instagram in India, with people in the age group of between 25 and 34 contributing to over $35 \%$. Another interesting aspect of this distribution is that the female users overtake the male users as the age increases after 34. Most of the females are known to pay particular attention to personal care and beautification products across the world and India. For this study the three most popular pages that are followed worldwide are considered, and some of the most popular brands and products that are preferred by youngsters and the older people are compared in this section.

\section{Pages Reviewing Beauty Products}

Table 1: Beauty Products Pages

\begin{tabular}{|l|c|}
\hline \multicolumn{2}{|c|}{ Pages Reviewing Beauty Products } \\
\hline \multicolumn{1}{|c|}{ Page } & Followers \\
\hline Pat Mcgrath & $3.2 \mathrm{M}$ \\
\hline Samantha Ravndahl & $2.1 \mathrm{M}$ \\
\hline CC Clarke Beauty & $2.1 \mathrm{M}$ \\
\hline
\end{tabular}

This self-explanatory table shows that beauty products have a huge following, as indicated by the pages shown above. This worldwide consumer following is most likely to translate into purchases shortly if not immediately. The three pages are only chosen as a part of the small sample to highlight the effect of social shopping, particularly for beauty products and personal care products among women. A product-wise break-up and user following are captured in the following table with number of views, likes, and comments to underline the degree of importance attached by consumers to these products in the chosen pages.

\section{Beauty Products \\ Pat Mcgrath}

Table 2: Views, Likes, Comments on Pat Mcgrath

\begin{tabular}{|l|c|c|c|}
\hline \multirow{2}{*}{\multicolumn{1}{c|}{ Products }} & \multicolumn{3}{c|}{ Pat Mcgrath } \\
\cline { 2 - 4 } & Views & Likes & Comments \\
\hline Eye shadow palette & 76,64 & 13,591 & 877 \\
\hline Concealer & 67,019 & 5958 & 218 \\
\hline Eyeliner & 90,285 & 10,43 & 199 \\
\hline Lipstick & 93,774 & 9736 & 588 \\
\hline Highlighter & 109,401 & 10,976 & 309 \\
\hline Foundation & 53,582 & 7173 & 176 \\
\hline
\end{tabular}

Highlighter and Eye shadow palette stand out as the most viewed, liked, or commented about products listed above. In comparison, the other products have received slightly lesser attention, although they also have attracted the interest of consumers. The second popular page by SAMANTHA RAVNDAHL also disclosed similar if not identical trends for the same set of products, as shown below.

\section{Samantha Ravndahl}

Table 3: Views, Likes, Comments on Samantha Ravndahl

\begin{tabular}{|l|c|c|c|}
\hline \multirow{2}{*}{\multicolumn{1}{|c|}{ Products }} & \multicolumn{3}{c|}{ Samantha Ravndahl } \\
\cline { 2 - 4 } & Views & Likes & Comments \\
\hline Eye shadow palette & 298,742 & 32,909 & 471 \\
\hline Concealer & 168,62 & 17,745 & 301 \\
\hline Eyeliner & 209,783 & 24,689 & 262 \\
\hline lipstick & 201,933 & 19,933 & 304 \\
\hline Highlighter & 222,649 & 18,618 & 289 \\
\hline Foundation & 301,316 & 31,477 & 463 \\
\hline
\end{tabular}

Interestingly this page discloses more interest in eye shadow palettes followed by the foundation in terms of views, likes, and comments. Highlighter is relegated to the third place as this stage is concerned. 
The other products more or less follow the same trend as in the previous page of PAT MCGRATH. It would be interesting to see how the consumers reacted to the 3rd popular page of CC CLARKE BEAUTY.

\section{Clarke Beauty}

Table 4: Views, Likes, Comments on CC Clarke Beauty

\begin{tabular}{|l|c|c|c|}
\hline \multirow{2}{*}{\multicolumn{1}{c|}{ Products }} & \multicolumn{3}{c|}{ CC Clarke Beauty } \\
\cline { 2 - 4 } & Views & Likes & Comments \\
\hline Eye shadow palette & $1,149,152$ & 107,350 & 680 \\
\hline Concealer & 358,022 & 63,807 & 311 \\
\hline Eyeliner & $1,884,548$ & 153,825 & 779 \\
\hline Lipstick & 219,443 & 46,010 & 338 \\
\hline Highlighter & 401,495 & 53,123 & 263 \\
\hline
\end{tabular}

Curiously, Eyeliner is on the top of this page with the highest views, likes, and comments, followed by Eye shadow palette. Both Foundation and Highlighter have respectively gone down one notch, taking third and fourth place. As for the other products, the consumer interest has almost remained neutral in comparison to the other two pages.

To understand the popularity of each page, a technique of weighing each aspect with a score and taking the cumulative score to rank all the pages has been followed. A weightage of $20 \%$ is given for views, $30 \%$ for likes and $50 \%$ for comments is allotted. The rationale for doing this is that the first reaction of a consumer can be identified by the views, likes, and comments that are expected to result in conversion into sales. The following table captures these aspects, as shown below.

Weightage of Page Dealing with Beauty Products Weightage of Pat Mcgrath

Table 5: Pat Mcgrath - Weightage

\begin{tabular}{|c|c|c|c|}
\hline Views & Likes & Comments & Total \\
\hline 1532.8 & 4077.3 & 438.5 & 6048.6 \\
\hline 13403.8 & 1787.4 & 109 & 15300.2 \\
\hline 18057 & 312.9 & 99.5 & 18469.4 \\
\hline 18754.8 & 2920.8 & 294 & 21969.6 \\
\hline 21880.2 & 3292.8 & 154.5 & 25327.5 \\
\hline 10716.4 & 2151.9 & 88 & 12956.3 \\
\hline & & & $1,00,071.6$ \\
\hline
\end{tabular}

\section{Weightage of Samantha Ravndahl}

Table 6: Samantha Ravndahl - Weightage

\begin{tabular}{|c|c|c|c|}
\hline Views & Likes & Comments & Total \\
\hline 59748.4 & 9872.7 & 235.5 & 69856.6 \\
\hline 3372.4 & 5323.5 & 150.5 & 8846.4 \\
\hline 41956.6 & 7406.7 & 131 & 49494.3 \\
\hline 40386.6 & 5979.9 & 152 & 46518.5 \\
\hline 44529.8 & 5585.4 & 144.5 & 50259.7 \\
\hline 60263.2 & 9443.1 & 231.5 & 69937.8 \\
\hline & & & $2,94,913.3$ \\
\hline
\end{tabular}

\section{Weightage of CC Clarke Beauty}

Table 7: CC Clarke Beauty - Weightage

\begin{tabular}{|c|c|c|c|}
\hline Views & Likes & Comments & Total \\
\hline 229830.4 & 32205 & 340 & 262375.4 \\
\hline 71604.4 & 19142.1 & 155.5 & 90902 \\
\hline 376909.6 & 46147.5 & 389.5 & 423446.6 \\
\hline 43888.6 & 13803 & 169 & 57860.6 \\
\hline 80299 & 15936.9 & 131.5 & 96367.4 \\
\hline 90139 & 15313.8 & 115 & 105567.8 \\
\hline & & & $10,36,520$ \\
\hline
\end{tabular}

\section{Ranking of Page Dealing with Beauty Products}

Table 8: Ranking of Pages

\begin{tabular}{|c|l|c|}
\hline S. No. & \multicolumn{1}{|c|}{ Page } & Rank \\
\hline 1 & Pat Mcgrath & 3 \\
\hline 2 & Samantha Ravndahl & 2 \\
\hline 3 & CC Clarke Beauty & 1 \\
\hline
\end{tabular}

Based on the technique adopted, the three pages are ranked based on the cumulative score (after due weightage). CC CLARKE BEAUTY is on the top of the list with over 1 million cumulative scores $(1,036,520)$, and the next page of SAMANTHA RAVNDAHL is far behind (294,913.3), almost $70 \%$ lower. The third page of PAT MCGRATH is also lower $(100,071.6)$, which is even lower than the second one compared with the 1st ranked CC CLARKE BEAUTY.

Turning attention to personal care products, a similar exercise was carried out, which are tabulated below. 
Pages Reviewing Personal Care Products

Table 9: Personal Care Products Pages

\begin{tabular}{|l|c|}
\hline \multicolumn{1}{|c|}{ Pages Reviewing Personal Care Products } \\
\hline Phe Beauty Bloss & Followers \\
\hline Nykaa Beauty Book & $48.8 \mathrm{~K}$ \\
\hline Gelcream & $335 \mathrm{~K}$ \\
\hline
\end{tabular}

The three popular pages for personal care going by the number of consumers following are slightly lesser in terms of numbers than beauty products. Page-wise product distribution and consumer reaction are captured below.

\section{Personal Care Products}

\section{The Beauty Bloss}

Table 10: Likes, Comments on the Beauty Bloss

\begin{tabular}{|l|c|c|}
\hline \multirow{2}{*}{ Products } & \multicolumn{2}{|c|}{ The Beauty Bloss } \\
\cline { 2 - 3 } & Likes & Comments \\
\hline Skin creams & 693 & 53 \\
\hline Face Serum & 1319 & 61 \\
\hline Hand cream & 745 & 77 \\
\hline Face Mask & 491 & 64 \\
\hline Toner & 712 & 48 \\
\hline
\end{tabular}

Despite the global lock-down or restricted business due to shopping limitations and delivery limitations, face serum and hand cream continue to be on top based on views, likes, and comments. Surprisingly the most important product, called face mask, is at the bottom, although people may find it difficult to access Spas and Beauty parlors in the current condition (COVID-19) due to fears of the pandemic and the need for social distancing. A similar trend is also witnessed in the second popular page, as shown below.

\section{Nykaa Beauty Book}

Table 11: Likes, Comments on Nykaa Beauty Book

\begin{tabular}{|l|c|c|}
\hline \multirow{2}{*}{ Products } & \multicolumn{2}{|c|}{ Nykaa Beauty Book } \\
\cline { 2 - 3 } & Likes & Comments \\
\hline Skin creams & 510 & 5 \\
\hline Face Serum & 688 & 8 \\
\hline Hand cream & 650 & 6 \\
\hline Face Mask & 1242 & 10 \\
\hline Toner & 1514 & 19 \\
\hline
\end{tabular}

This popular page has more consumer interest for toner followed by a face mask. Perhaps, people have their page preferences for each product because the face mask was low down the order in THE BEAUTY BLOSS page, whereas it ranks higher at number 2 on this page. On the other hand, face serum was on the top in THE BEAUTY BLOSS, whereas it is low down the order on this page. It is necessary to see if this view is substantiated in the third popular page, GEL CREAM.

\section{Gel Cream}

Table 12: Likes, Comments on Gel Cream

\begin{tabular}{|l|c|c|}
\hline \multirow{2}{*}{\multicolumn{1}{|c|}{ Products }} & \multicolumn{2}{c|}{ Gelcream } \\
\cline { 2 - 3 } & Likes & Comments \\
\hline Skin creams & 4097 & 95 \\
\hline Face Serum & 1847 & 34 \\
\hline Hand cream & 5127 & 69 \\
\hline Face Mask & 5903 & 144 \\
\hline Toner & 3658 & 270 \\
\hline
\end{tabular}

Both face mask and toner are neck-to-neck in this page based on the likes and comments of followers. Not surprisingly, face serum is at the bottom, vindicating the view expressed earlier about consumer preferences of products on each page. Based on the consumer following these pages, a similar weighing technique is adopted, as was done earlier to rank all the pages from the product point of view. This is represented in the following tables.

\section{Weightage of Page Dealing with Personal Care Products}

Weightage of the Beauty Bloss

Table 13: The Beauty Bloss - Weightage

\begin{tabular}{|c|c|c|}
\hline Likes & Comments & Total \\
\hline 277.2 & 31.8 & 309 \\
\hline 527.6 & 36.6 & 564.2 \\
\hline 298 & 46.2 & 344.2 \\
\hline 196.4 & 38.4 & 234.8 \\
\hline 284.8 & 28.8 & 313.6 \\
\hline & & 1765.8 \\
\hline
\end{tabular}




\section{Weightage of Nykaa Beauty Book}

Table 14: Nykaa Beauty Book - Weightage

\begin{tabular}{|c|c|c|}
\hline Likes & Comments & Total \\
\hline 204 & 3 & 207 \\
\hline 275.2 & 4.8 & 280 \\
\hline 260 & 3.6 & 263.6 \\
\hline 496.8 & 6 & 502.8 \\
\hline 605.6 & 11.4 & 617 \\
\hline & & 1870.4 \\
\hline
\end{tabular}

\section{Weightage of Gel Cream}

Table 15: Gel Cream - Weightage

\begin{tabular}{|c|c|c|}
\hline Likes & Comments & Total \\
\hline 1638.8 & 57 & 1695.8 \\
\hline 738.8 & 20.4 & 759.2 \\
\hline 2050.8 & 41.4 & 2092.2 \\
\hline 2361.2 & 86.4 & 2447.6 \\
\hline 1463.2 & 162 & 1625.2 \\
\hline & & 8620 \\
\hline
\end{tabular}

Ranking of Page Dealing with Personal Care Products

Table 16: Ranking of Pages

\begin{tabular}{|c|l|c|}
\hline S. No. & \multicolumn{1}{|c|}{ Page } & Rank \\
\hline 1 & The Beauty Bloss & 3 \\
\hline 2 & Nykaa Beauty Book & 2 \\
\hline 3 & Gelcream & 1 \\
\hline
\end{tabular}

It is evident from the table above that GEL CREAM is ranked number 1 from the products' views and likes, although it has 120 thousand followers as compared to NYKAA BEAUTY BOOK with 335 thousand followers. THE BEAUTY BLOSS is at the bottom not only because of the lesser number of followers (48 thousand) but also because of the choice of products by consumers for social shopping. It would be appropriate to see how the ratings influence purchase behavior, particularly in leading online shopping portals like AMAZON. This is because people turn to INSTAGRAM pages to select products and online E-commerce portal for purchase of the same. The following table captures the rating and number of reviews for the chosen products.
Instagram Brands and their Amazon Rating Brands in Beauty Products

Table 17: Beauty Products Brands

\begin{tabular}{|l|c|}
\hline \multicolumn{1}{|c|}{ Brand Name } & Followers \\
\hline Maybelline New York & $10.3 \mathrm{M}$ \\
\hline Loreal Paris & $8.7 \mathrm{M}$ \\
\hline Lakme India & $1.5 \mathrm{M}$ \\
\hline
\end{tabular}

The above table revels that the top 2 brands are way ahead in AMAZON going by the number of followers. LAKME INDIA is lagging far behind with only 1.5 million followers as against 10.3 million and 8.7 million for MAYBELLINE NEW YORK and LOREAL PARIS, respectively. This is understandable because LAKME is an Indian brand that is yet to become popular among INSTAGRAM users worldwide.

\section{Amazon Rating of Beauty Products}

Table 18: Ratings, Reviews of Products Maybelline New York

\begin{tabular}{|l|c|c|}
\hline \multirow{2}{*}{ Products } & \multicolumn{2}{|c|}{ Maybelline New York } \\
\cline { 2 - 3 } & Rating & No. of Customers Reviewed \\
\hline Lipstick & 3.9 & 8861 \\
\hline Foundation & 4.1 & 890 \\
\hline Eye Palette & 3.8 & 1408 \\
\hline Mascara & 3.8 & 3493 \\
\hline Nail Paint & 4 & 688 \\
\hline
\end{tabular}

The beauty products of MAYBELLINE NEWYORK enjoy a good rating for at least two of its products, foundation and nail paint, whereas lipstick enjoys more views because people are keen on buying this product because of a 3.9 rating. Both mascara and eye palette also enjoy a rating of 3.8, which is by no means insignificant. There are also opinions expressed about the reason for the foundation being on top because of the limited options compared to lipstick, which has more than 100 options.

Table 19: Ratings, Reviews of Products - Loreal Paris

\begin{tabular}{|l|c|c|}
\hline \multirow{2}{*}{ Products } & \multicolumn{2}{|c|}{ Loreal Paris } \\
\cline { 2 - 3 } & Rating & No. of Customers Reviewed \\
\hline Lipstick & 3.9 & 876 \\
\hline Foundation & 3.8 & 4313 \\
\hline
\end{tabular}




\begin{tabular}{|l|c|c|}
\hline Eye Palette & 4.3 & 21 \\
\hline Mascara & 3.8 & 1979 \\
\hline Nail Paint & 4 & 693 \\
\hline
\end{tabular}

Interestingly the trend is completely reverse in LOREAL PARIS, where the eye palette is on top and foundation and mascara are at the bottom. This may indicate consumer preferences for particular products in each brand. The reviews however, are more for the foundation in this brand.

Table 20: Ratings, Reviews of Products - Lakme India

\begin{tabular}{|l|c|c|}
\hline \multirow{2}{*}{ Products } & \multicolumn{2}{|c|}{ Lakme India } \\
\cline { 2 - 3 } & Rating & No. of Customers Reviewed \\
\hline Lipstick & 3.8 & 6840 \\
\hline Foundation & 3.9 & 1635 \\
\hline Eye Palette & 3.8 & 480 \\
\hline Mascara & 3.9 & 2806 \\
\hline Nail Paint & 3.8 & 2658 \\
\hline
\end{tabular}

The LAKME products also exhibit a similar trend like LOREAL PARIS with foundation and mascara being on top with a rating of 3.9 while the others are close behind with a rating of 3.8. The review is however, are more for lipstick for the reasons mentioned earlier (more options for shades).

The consumer perception of the brands and products can be gauged by looking at the positive and negative comments for the products.

\section{Positive Reviews/ Comments in Amazon}

Table 21: Amazon - Positive Reviews/Comments

\begin{tabular}{|c|l|}
\hline \multicolumn{1}{|c|}{ Mroducts } & \multicolumn{1}{c|}{ Reviews } \\
\hline Lipstick & $\begin{array}{l}\text { The best thing about this lipstick is that } \\
\text { it's got matt finish without being the least } \\
\text { bit dry. It feels creamy and comfortable. } \\
\text { It also stays for a long time without } \\
\text { caking or looking dry. }\end{array}$ \\
\hline Foundation & $\begin{array}{l}\text { Love this foundation. So far had been } \\
\text { using glass bottle version, but this tube } \\
\text { is much more convenient for travelling. } \\
\text { Medium coverage, light weight formula, } \\
\text { matte finish. Even out skin tone very } \\
\text { well, but won't really hide dark spots on } \\
\text { the skin. But light enough to use every } \\
\text { day for natural make-up look. }\end{array}$ \\
\hline
\end{tabular}

\begin{tabular}{|l|l|}
\hline Eye Palette & $\begin{array}{l}\text { Awesome product by Maybelline. } \\
\text { Experimenting with colours now. }\end{array}$ \\
\hline Mascara & $\begin{array}{l}\text { This mascara is wonderful. Don't hesitate } \\
\text { to buy it seeing the bad comments. Its } \\
\text { smudge proof, waterproof, long lasting, } \\
\text { you can remove t easily by coconut oil. }\end{array}$ \\
\hline Nail Paint & $\begin{array}{l}\text { Does not chip off easily, long lasting, } \\
\text { affordable }\end{array}$ \\
\hline
\end{tabular}

Table 22: Amazon - Positive Reviews/Comments

\begin{tabular}{|c|c|}
\hline \multicolumn{2}{|r|}{ Loreal Paris } \\
\hline Products & Reviews \\
\hline Lipstick & $\begin{array}{l}\text { The texture feels velvety, gives some- } \\
\text { what creamy smooth finish on lips. Will } \\
\text { look beautiful on fair skin even if take } \\
\text { the lipstick off it leaves a stain on your } \\
\text { lips which is kind of good if you cover it } \\
\text { up with a transparent lip balm. }\end{array}$ \\
\hline Foundation & $\begin{array}{l}\text { It works as claimed. Medium cover- } \\
\text { age with a demi-matte finish, I wore it } \\
\text { for back to back functions from } 11 \mathrm{am}- \\
11 \mathrm{pm} \text { and it stayed without cracking or } \\
\text { turning patchy. Till } 11 \mathrm{pm} \text { when I took it } \\
\text { off, my make-up looked fresh. It doesn't } \\
\text { oxidise like the Maybelline Fit Me Pore- } \\
\text { less Matte }\end{array}$ \\
\hline Eye Palette & Good colours \\
\hline Mascara & $\begin{array}{l}\text { It's a great mascara. Lasts long and does } \\
\text { not powder. Does a great job of volu- } \\
\text { mizing and staying put all day? The wa- } \\
\text { terproof version makes it a little hard to } \\
\text { remove. }\end{array}$ \\
\hline Nail Paint & $\begin{array}{l}\text { The colour is rich and dries quickly. En- } \\
\text { hances even the look of a medium com- } \\
\text { plexion wearer. Suits fairer skin. }\end{array}$ \\
\hline
\end{tabular}

Table 23: Amazon - Positive Reviews/Comments

\begin{tabular}{|c|l|}
\hline \multicolumn{2}{|c|}{ Lakme India } \\
\hline Products & \multicolumn{1}{c|}{ Reviews } \\
\hline Lipstick & $\begin{array}{l}\text { Love the shade, it brightens your look, } \\
\text { without being loud. Plan to use it as a } \\
\text { day-wear lipstick. If you have used } \\
\text { 'Red Chaos' in the past, this is simi- } \\
\text { lar to that. The formulation is slightly } \\
\text { drying, you will need to prep the lips } \\
\text { before application if you have dry lips. }\end{array}$ \\
\hline Foundation & $\begin{array}{l}\text { Sweat proof, lasts the entire day, even } \\
\text { skin tone, perfect finish, oil free look }\end{array}$ \\
\hline
\end{tabular}




\begin{tabular}{|l|l|}
\hline \multirow{2}{*}{ Eye Palette } & $\begin{array}{l}\text { Palette is compact. Travel friendly. It } \\
\text { includes basic colours which can match } \\
\text { with every casual dresses. It has little } \\
\text { bit of shimmer only. }\end{array}$ \\
\hline Mascara & $\begin{array}{l}\text { Mascara lasts very long and top is easy } \\
\text { and perfect to apply very happy with } \\
\text { my product. }\end{array}$ \\
\hline Nail Paint & $\begin{array}{l}\text { Beautiful colour, original product, price } \\
\text { of the product is affordable }\end{array}$ \\
\hline
\end{tabular}

Negative Reviews/ Comments in Amazon

Table 24: Amazon - Negative Reviews/Comments

\begin{tabular}{|l|l|}
\hline \multicolumn{2}{|c|}{ Maybelline New York } \\
\hline Products & \multicolumn{1}{c|}{ Reviews } \\
\hline Lipstick & $\begin{array}{l}\text { The colour is very nice. But the quality } \\
\text { is rough, it wasn't so when I opened the } \\
\text { package. Gradually it getting granular. } \\
\text { I have used Maybelline lipstick several } \\
\text { times and they were all very good. So, } \\
\text { this particular one is very disappointing. } \\
\text { May be this piece is defective. Anoth- } \\
\text { er strange thing is that I observed there } \\
\text { was a price tag on the lipstick with MRP } \\
\text { 299/- whereas I paid the regular price, } \\
\text { 450. Kindly look into the matter and } \\
\text { check who was the seller. }\end{array}$ \\
\hline Foundation & Very little quantity \\
\hline Eye Palette & $\begin{array}{l}\text { The product is nothing like it appears on } \\
\text { screen. The shimmer or glitter is just the } \\
\text { top layer of the eyeshadow, and then it's } \\
\text { very dull and unappealing. }\end{array}$ \\
\hline Mascara & $\begin{array}{l}\text { Don't buy this product its dry and started } \\
\text { itching my eyes once applied }\end{array}$ \\
\hline Nail Paint & $\begin{array}{l}\text { Colour is not as same as shown in the } \\
\text { picture }\end{array}$ \\
\hline
\end{tabular}

Table 25: Amazon - Negative Reviews/Comments

\begin{tabular}{|l|l|}
\hline \multicolumn{2}{|c|}{ Loreal Paris } \\
\hline Products & \multicolumn{1}{c|}{ Reviews } \\
\hline Lipstick & Product was broken from inside \\
\hline Foundation & $\begin{array}{l}\text { The colour range is quite poor and I } \\
\text { am stuck between 2 shades. L'Oréal } \\
\text { might be a drugstore brand but they } \\
\text { need to expand the shade range. }\end{array}$ \\
\hline Eye Palette & $\begin{array}{l}\text { Damaged product received from } \\
\text { amazon }\end{array}$ \\
\hline
\end{tabular}

\begin{tabular}{|l|l|}
\hline \multirow{3}{*}{ Mascara } & $\begin{array}{l}\text { Everything about this product is bad. } \\
\text { Can't believe this is L'Oreal. This } \\
\text { is like semi solid carbon. Eyelashes } \\
\text { never look separate and beautiful. } \\
\text { They look sticky. To remove this is } \\
\text { impossible. The brush a liquid is too } \\
\text { thick }\end{array}$ \\
\hline Nail Paint & $\begin{array}{l}\text { I received a CND Vinyl lux in an } \\
\text { awful colour. I am disgusted with this } \\
\text { experience. }\end{array}$ \\
\hline
\end{tabular}

Table 26: Amazon - Negative Reviews/Comments

\begin{tabular}{|c|l|}
\hline \multicolumn{2}{|c|}{ Lakme India } \\
\hline Products & \multicolumn{1}{|c|}{ Reviews } \\
\hline Lipstick & $\begin{array}{l}\text { Colour is a little different when applied } \\
\text { on the lips. Smooth texture. Nice smell. } \\
\text { Stays longer. But lips feel drier. }\end{array}$ \\
\hline Foundation Palette & $\begin{array}{l}\text { After applying I felt burning sensation. } \\
\text { Will not recommend. }\end{array}$ \\
\hline Mascara & $\begin{array}{l}\text { Product was not sealed properly and } \\
\text { even though the product has 3 years of } \\
\text { expiry only 8 months was left when I got } \\
\text { the product. }\end{array}$ \\
\hline Nail Paint & $\begin{array}{l}\text { Worst mascara ever. Mouth of the bottle } \\
\text { is so wide that when you pull the brush it } \\
\text { is totally covered with black cream and } \\
\text { all you can see is a long stick entirely } \\
\text { covered with black cream. }\end{array}$ \\
\hline $\begin{array}{l}\text { Coverage is not good at all. its chipping } \\
\text { out in a single day and the application is } \\
\text { also not smooth. It's too thick for apply- } \\
\text { ing an even coat. }\end{array}$ \\
\hline
\end{tabular}

The comments are indicative of the purchase behavior of consumers and their impact on sales. A satisfied consumer is a brand ambassador because she will promote her circle and share her good experience. On the other hand, the dissatisfied customers would share negative comments in the open forum, affecting the rating and the purchase decision of other consumers. Looking at personal products for rating and views following information is obtained and tabulated. Only two products have been considered in this study for personal care products. 
Brands in Personal Care Products

Table 27: Personal Care Products Brands

\begin{tabular}{|l|c|}
\hline \multicolumn{1}{|c|}{ Brand Name } & Followers \\
\hline Wow Skincare India & $210 \mathrm{k}$ \\
\hline Biotique & $346 \mathrm{k}$ \\
\hline
\end{tabular}

The two products, namely WOW SKINCARE and BIOTIQUE, are also popular on Instagram with over 210 thousand and 346 thousand followers, respectively. How this reflects in rating at AMAZON is tabulated below.

\section{Amazon Rating of Personal Care Products}

Table 28: Ratings, Reviews of Products - Wow

Skincare

\begin{tabular}{|l|c|c|}
\hline \multirow{2}{*}{ Products } & \multicolumn{2}{|c|}{ Wow Skincare } \\
\cline { 2 - 3 } & Rating & No. of Customers Reviewed \\
\hline Moisturiser & 4.1 & 138 \\
\hline Face Wash & 4.2 & 4746 \\
\hline Shampoo & 3.8 & 14,930 \\
\hline Hair Oil & 3.9 & 2392 \\
\hline Body Wash & 4.2 & 162 \\
\hline
\end{tabular}

Both face wash and body wash are on top with a rating of 4.2 , whereas the other three products are just below with ratings of $4.1,3.9$, and 3.8 , respectively. This is an indication that the consumer base for all the products of this brand is quite high, and this is also reflected in the views that are looked at.

Table 29: Ratings, Reviews of Products-Biotique

\begin{tabular}{|l|c|c|}
\hline \multirow{2}{*}{ Products } & \multicolumn{2}{|c|}{ Biotique } \\
\cline { 2 - 3 } & Rating & No. of Customers Reviewed \\
\hline Moisturiser & 4.3 & 22 \\
\hline Face Wash & 4.1 & 2325 \\
\hline Shampoo & 3.9 & 1776 \\
\hline Hair Oil & 4 & 3044 \\
\hline Body Wash & 4.4 & 2950 \\
\hline
\end{tabular}

A similar trend with slightly higher ratings is visible for BIOTIQUE products, with body wash on top with a rating of 4.4 closely followed by the other products with reasonably good ratings. In terms of views also there is more or less a similar trend except for that hair oil and body wash are on top whereas the other three products are slightly behind.

It would be interesting to capture some positive and negative comments for both brands with the respective products. This is tabulated below.

\section{Positive Reviews/ Comments in Amazon}

Table 30: Amazon - Positive Reviews/Comments

\begin{tabular}{|c|l|}
\hline \multicolumn{2}{|c|}{ Wow Skincare India } \\
\hline Products & \multicolumn{1}{c|}{ Review } \\
\hline Moisturiser & $\begin{array}{l}\text { The moisturiser is very lightweight, } \\
\text { gives matte finish and very nice smell }\end{array}$ \\
\hline Face Wash & $\begin{array}{l}\text { One of the best faces wash I have ever } \\
\text { used. Because brush is attached to it so } \\
\text { it is easy to wash face. Not at all harsh } \\
\text { to skin. Cleanses face. Removes dead } \\
\text { skin cells }\end{array}$ \\
\hline Shampoo & $\begin{array}{l}\text { Great shampoo for dry hair when you } \\
\text { use it with herbal + coconut oil }\end{array}$ \\
\hline Hair Oil & $\begin{array}{l}\text { Have been using it over a year. Great } \\
\text { results, baldness gone within months of } \\
\text { application. Don't waste your money } \\
\text { on hair transplant. Buy this product it } \\
\text { will naturally stimulate hair growth }\end{array}$ \\
\hline Body Wash & $\begin{array}{l}\text { The body wash feels natural and organ- } \\
\text { ic with the aroma of the apple cider and } \\
\text { a hint of vinegar. The skin is refreshed } \\
\text { use. Definitely value for money and } \\
\text { better than any other big brands. }\end{array}$ \\
\hline
\end{tabular}

Table 31: Amazon - Positive Reviews/Comments

\begin{tabular}{|c|l|}
\hline \multicolumn{1}{|c|}{ Biotique } \\
\hline Products & \multicolumn{1}{|c|}{ Review } \\
\hline Moisturiser & $\begin{array}{l}\text { I have been using the product since last } \\
10-15 \text { days. Keeps skin hydrated and } \\
\text { makes it softer. Really good moisturiser }\end{array}$ \\
\hline Face Wash & $\begin{array}{l}\text { Will keep buying until I find something } \\
\text { better which is highly doubtful } \\
\text { considering what this face wash delivers } \\
\text { at such an affordable price point. } \\
\text { Cleanses my dehydrated skin leaving } \\
\text { behind soft and really clean skin. No } \\
\text { dryness whatsoever that I can even skip } \\
\text { moisturiser when I feel super lazy }\end{array}$ \\
\hline Shampoo & $\begin{array}{l}\text { I have been using this shampoo for } 6 \\
\text { months and find it useful. It is very } \\
\text { economical devoid of any chemicals. } \\
\text { Helps in arresting hair fall and nourishes } \\
\text { well. It will not give a cosmetic finish like } \\
\text { most departmental store or expensive } \\
\text { brands but is truly therapeutic. It is a } \\
\text { basic shampoo which does what it says. }\end{array}$ \\
\hline
\end{tabular}




\begin{tabular}{|l|l|}
\hline \multirow{5}{*}{ Hair Oil } & $\begin{array}{l}\text { Love this product. I was having major } \\
\text { hair fall issue before applying this. After } \\
\text { I started using this, my hair fall reduced } \\
\text { to a great extent. Issue this before } \\
\text { the day I shampoo my hair. I use it at } \\
\text { night and only on the scalp and leave } \\
\text { it overnight and wash my hair the next } \\
\text { day. Best hair oil I've ever used. I got } \\
\text { myself the } 800 \text { ml bottle this time. }\end{array}$ \\
\hline Body Wash & $\begin{array}{l}\text { I used it first in a resort during travel. I } \\
\text { loved the smell so much that I ordered } \\
\text { my own at home. Its awesome fragrance, } \\
\text { gentle feeling, and its paraben free. I } \\
\text { hope it is 100\% natural and ayurvedic } \\
\text { like they claim. It lathers softly and } \\
\text { leaves a nice smell and feel after shower. }\end{array}$ \\
\hline
\end{tabular}

Negative Reviews/ Comments In Amazon:

Table 32: Amazon - Negative Reviews/Comments

\begin{tabular}{|c|l|}
\hline \multicolumn{2}{|c|}{ Wow Skincare India } \\
\hline Products & \multicolumn{1}{c|}{ Review } \\
\hline Moisturiser & $\begin{array}{l}\text { Check the ingredients list before } \\
\text { buying. It has artificial fragrance and } \\
\text { applying my face starts sweating. Buy } \\
\text { only comedogenic and fragrance-free } \\
\text { moisturiser. }\end{array}$ \\
\hline Face Wash & $\begin{array}{l}\text { It didn't suit me at all. got more pimples } \\
\text { on my face. And even purchased wow } \\
\text { shampoo conditioner and oil but all are } \\
\text { worst }\end{array}$ \\
\hline Shampoo & $\begin{array}{l}\text { Makes my hair greasy. It's supposed to } \\
\text { give your hair shine }\end{array}$ \\
\hline Body Wash & $\begin{array}{l}\text { It's nice but not giving any lightening to } \\
\text { my skin. Giving very dull look. } \\
\text { wow about it. You can purchase this } \\
\text { product as a normal hair oil but don't } \\
\text { expect miracle or hair growth, as claimed } \\
\text { by this product, at all. }\end{array}$ \\
\hline
\end{tabular}

Table 33: Amazon - Negative Reviews/Comments

\begin{tabular}{|c|l|}
\hline \multicolumn{2}{|c|}{ Biotique } \\
\hline Products & \multicolumn{1}{|c|}{ Review } \\
\hline Moisturiser & (No bad comments) \\
\hline Face Wash & $\begin{array}{l}\text { It is neutral, doesn't do anything, waste } \\
\text { of money.... Bought this after reading } \\
\text { reviews but it does not even serve } \\
\text { purpose of normal face packs. }\end{array}$ \\
\hline
\end{tabular}

\begin{tabular}{|l|l|}
\hline Shampoo & $\begin{array}{l}\text { It is not suitable for dry hair and dry } \\
\text { scalp. I am having more hair fall after } \\
\text { using it a couple of times. Though they } \\
\text { say it is an organic product, they only } \\
\text { mention a few names in the ingredient } \\
\text { list. }\end{array}$ \\
\hline Hair Oil & $\begin{array}{l}\text { I thought it was organic and went for it. } \\
\text { But it sorts of increased my hair fall }\end{array}$ \\
\hline Body Wash & $\begin{array}{l}\text { After going through the review, I thought } \\
\text { to give it a try and found that there is } \\
\text { nothing special in it. It's just liked a } \\
\text { normal body wash. I neither sensed any } \\
\text { refreshing feel nor any aroma }\end{array}$ \\
\hline
\end{tabular}

The above comments bring out the dynamics of consumer perception about the products under consideration. While one set of consumers gives a very positive review for moisturizer of both brands, there are others who raised doubts about the content, the nature of flavor (artificial), and its effect on skin type. Hence, the popular age-old victim of "Caveat Emptor" (let the buyer beware) holds good even today.

\section{Findings and Conclusion}

The analysis and discussion in the preceding section of this paper have led to some interesting aspects summarized as findings below. Although the study relied entirely on secondary data, the ordeal of compiling page wise and product wise information from INSTAGRAM called for an eye-for-detail which was reasonably adhered to. More importantly, the information has been gathered for internationally recognized and followed pages and brands that are very popular among consumers in their capacity as users and beauticians.

\section{Findings}

1. First and foremost, the follower base for INSTAGRAM has been growing tremendously over the last seven years, and it stands at over 1 billion today. It contributes to $67 \%$ of the advertisement revenue of FACEBOOK and has started attracting more social E-commerce firms and shopping consumers.

2. US and INDIA together account for over $20 \%$ of the total users and more than $25 \%$ of the active users as in April 2020. As a result, INSTAGRAM 
has become a preferred destination for many products but more particularly, Personal care and beauty products both for the shoppers and the manufacturers (83\% beauty products and 39\% for personal care products).

3. Interestingly, the most active users (35\%) are in the age group of 25-34, with female users increasing in percentage as the age goes up.

4. India may well emerge as the biggest social shopping platform through INSTAGRAM because the major cohort of the population (60\%) is young in between 18 and 50. Since people in this age group are more conscious about both appearance and personal care, the pages and the branded products advertised in this platform are likely to increase shortly.

5. Internationally, the most popular pages belong to the big name in the industry. Sooner or later, smaller players may enter this fray with retail brands to compete with manufacturer driven brands.

6. Beauty products have managed to enjoy a higher rating in the most popular online platform, AMAZON, compared to Personal care products, although the brands are different.

7. The growing awareness among women about maintaining skin tone, texture, and skin health has contributed significantly to the increased follower based in Instagram, thus becoming a leading social shopping portal for buyers and sellers to come together. This is evidence to buy the fact that the volume of business through Instagram for the manufacturers and Instagram itself has grown considerably over the years.

8. While the consumer shopping through Instagram amounted to over $36 \%$, about $87 \%$ of the people claimed that they use the INSTAGRAM platform in making the purchase decision according to eMarketer Study.

The number of marketers who use INSTAGRAM for businesses has risen from $53 \%$ to $73 \%$ over the last three years, thus proving the strength of the platform to attract buyers and sellers.

\section{Conclusion}

The term serendipity, which is used to describe an accidental discovery, may well be the best words to describe social media networks because the intentions with which they were started are not the same as the users to which they are currently applied. What started as a simple attempt to bring people together to networking has now magnified into a high potential social E-commerce platform growing at a staggering pace today. The innovation in application development has reached the next level, with more and more customized applications taking a prominent position in social media. For instance, apps that help consumers to try the fashion products on themselves before a purchase, the suitability of beauty products for an individual that can be easily ascertained by superimposing the product on the customer's photograph (like a lipstick, foundation, eyeliner, eye shadow and many more) have all enabled the ease of online shopping without worrying about the fit of the product for the consumer. The seamless integration of digital technology with applications has resulted in remote shopping emerging as a strong contender to offline stores. This has never been appreciated so much as today when the woman has to give-up their compelling habit of shopping in stores due to mandated lockdown or the worries about the community spread of COVID-19. During these monotonous times, when people are pinned to their homes, social shopping is considered more an entertainment than even a shopping convenience. The world is evolving today into a technology-driven business model where all aspects of daily life, such as banking, finance, investment shopping, and even self-beautification, may be aided by digitization and innovation. Sooner or later, even spas and parlors may go virtual and help their customers to learn the tricks of making up and preserving their face and body through online demonstrations of specialized skills. This business model may move away from a skill-based execution to that of an advisory or consultancy service. The customized products can all be sourced through social shopping, and the art of beautification may well become a cottage industry. The success of any business today lies in its ability to bring about the seamless integration of people, processes, and technology to achieve cuttingedge cost efficiency and process efficiency. Social media networks may well emerge as the facilitators to achieve this end by unifying themselves into 
every function of every business, although they are experimenting with the market today. Along with payment banks, social media networks like FACEBOOK, INSTAGRAM, TWITTER, and others are likely to take up financial intermediation, investment banking to promote fundraising through IPOs or convert them into recruitment platforms by bringing all the stakeholders on a common platform. This may sound a little far-fetched today, but it may well become a compelling reality in the future.

\section{References}

Abbamonte, Kiera. "Social Commerce for Retail: What is it and 3 Examples of Retailers Doing it Well." Shopify, 2018.

Abed, Salma. "An Empirical Examination of Instagram as an S-Commerce Channel." Journal of Advances in Management Research, vol. 15, no. 2, 2018, pp. 146-160.

Bond, Conor. "Social Shopping for Beginners: How to Sell on Facebook \& Instagram." Wordstream, 2019.

Boyle, Pete. "The Secret to the Future Growth of Your Ecommerce Channel: Social Commerce." BigCommerce.
Chen, Jenn. "Important Instagram Stats you Need to Know for 2020." SproutSocial.

Finlay, Shane. "Social Commerce Will Change the World - Here's How to Get It Right." Digitalist, 2018.

Gilliland, Nikki. "Are People Buying on Social Media?" Econsultancy, 2018.

Hoey, Morgan. "Narratives Brands and Consumers Create about Social Commerce." SSML.

Iqbal, Mansoor. "Instagram Revenue and Usage Statistics (2020).” Business of Apps, 2020.

Millwood, Aimee. "Top Social Commerce Trends for 2016." Yotpo, 2015.

Mullin, Shanelle. "Social Commerce: What it is, What it isn't, and Why You Should Care." CXL, 2019.

Olbrich, Rainer, and Christian Holsing. "Modeling Consumer Purchasing Behavior in Social Shopping Communities with Clickstream Data." International Journal of Electronic Commerce, vol. 16, no. 2, 2011, pp. 15-40.

Wooley, Andy. "Reasons to Use Social-Shopping Sites and Social Retail Apps." OnSpot, 2019.

\section{Author Details}

Dr. T. Gayathri, Assistant Professor, Department of Commerce, Nehru Memorial College (A), Thiruchirapalli, Tamil Nadu, India

S. Preethi, Research Scholar, Nehru Memorial College, Thiruchirapalli, Tamil Nadu, India 